\title{
Anti-diabetes effect of water containing hydrogen molecule and Pt nanoparticles
}

\author{
Sanetaka Shirahata ${ }^{1,2^{*}}$, Takeki Hamasaki ${ }^{1}$, Keisuke Haramaki ${ }^{2}$, Takuro Nakamura', Masumi Abe ${ }^{1}$, Hanxu Yann ${ }^{2}$, \\ Tomoya Kinjo ${ }^{2}$, Noboru Nakamichi ${ }^{3}$, Shigeru Kabayama ${ }^{3}$, Kiichiro Teruya ${ }^{1,2}$ \\ From 22nd European Society for Animal Cell Technology (ESACT) Meeting on Cell Based Technologies \\ Vienna, Austria. 15-18 May 2011
}

\section{Background}

Electrochemically reduced water (ERW) contains a lot of hydrogen molecule $\left(\mathrm{H}_{2}\right)$ and scavenges reactive oxygen species (ROS) to protect DNA from oxidative damage [1]. ERW also contains small amounts of Pt nanoparticles (NPs) and elongates the lifespan of C. elegans [2]. $\mathrm{Pt}$ NPs are newly recognized multi-functional ROS scavengers [3]. ERW exhibits anti-diabetes effects in vitro and in vivo [4-6][7]. We proposed mineral nanoparticle active hydrogen reduced water hypothesis to explain the activation mechanism of $\mathrm{H}_{2}$ to hydrogen atom $(\mathrm{H})$ [4]. Recently, $\mathrm{H}_{2}$ has been reported to scavenge ROS and suppress a variety of oxidative stress-related diseases [8], however, the action mechanism of $\mathrm{H}_{2}$ has not been clarified thoroughly. Here, we examined anti-diabetes effects of $\mathrm{H}_{2}$ and Pt NPs.

\section{Materials and methods}

Pt NPs of 2-3 nm sizes were synthesized from $\mathrm{H}_{2} \mathrm{PtCl}_{6}$ by the citrate reduction method. L6 rat myoblast cells $\left(1.2 \times 10^{5}\right.$ cells $)$ were inoculated into a $35 \mathrm{~mm}$ culture dish and a day later, the cells were treated with or without $25 \mathrm{mM} \mathrm{N}$-acetylcystein in the presence of BES$\mathrm{H} 2 \mathrm{O} 2$, a $\mathrm{H}_{2} \mathrm{O}_{2}$-specific detection reagent in DMEM for $2 \mathrm{~h}$. After washing the cells, molecular hydrogen treatment was performed in a dark condition by cultivating cells in a fresh DMEM medium in a mixed gas incubator under an atmosphere of $75 \% \mathrm{~N}_{2} / 20 \% \mathrm{O}_{2} / 5 \% \mathrm{CO}_{2}$ or $75 \%\left(\mathrm{H}_{2}\right.$ and $\mathrm{N}_{2}$ mixed gas $) / 20 \% \mathrm{O}_{2} / 5 \% \mathrm{CO}_{2}$ for $1.5 \mathrm{~h}$, followed by flowcytometric analysis. In this condition, culture medium contained maximum $0.4-0.5 \mathrm{ppm}$ of dissolved hydrogen. Glucose uptake of differentiated

\footnotetext{
* Correspondence: sirahata@grt.kyushu-u.ac.jp

'Department of Bioscience and Biotechnology, Faculty of Agriculture, Kyushu

University, 6-10-1 Hakozaki, Higashi-ku, Fukuoka 812-8581, Japan

Full list of author information is available at the end of the article
}

myotube L6 cells was examined after treating the cells with ${ }^{3} \mathrm{H}$-2-deoxyglucose for $10 \mathrm{~min}$. Gene expression of catalase (CAT), glutathione peroxidase (GPx) and hemoxoigenase (HO-1) was examined using RT-PCR method. Three weeks old type 2 diabetes model mice $\left(\mathrm{KK}-A^{y}\right.$ ) were fed $\mathrm{H}_{2}$ and/or Pt Nps-containing water ad lib for 6 weeks.

\section{Results}

$\mathrm{H}_{2}$ stimulated glucose uptake into L6 cells. Pt NPs catalyzed the activation of $\mathrm{H}_{2}$ to hydrogen atom $(\mathrm{H})$ to scavenge DPPH radical in vitro. The combined use of molecular hydrogen and Pt NPs resulted in extremely stimulated glucose uptake into L6 cells, suggesting that $\mathrm{H}$ produced from $\mathrm{H}_{2}$ by catalyst action of Pt NPs regulated glucose uptake signal transduction. As oppose to the paper by Ohsawa et al.[8], $\mathrm{H}_{2}$ of 25 to $75 \%$ concentration in the mixed gas significantly scavenged intracellular $\mathrm{H}_{2} \mathrm{O}_{2}$ in rat fibroblast L6 cells (Figure 1) and induced the gene expression of antioxidative enzymes such as CAT, GPx and HO-1 via activation of Nrf2 (Figure 2). $\mathrm{H}_{2}$, Pt NPs and their combination significantly suppressed the levels of fasting blood glucose and improved the impaired sugar tolerance abilities of obese insulin-resistant type 2 diabetic KK- $A^{y}$ mice.

\section{Conclusion}

$\mathrm{H}_{2}$, Pt NPs, and their combined use resulted in activation of glucose uptake signal transduction pathways and stimulation of glucose uptake into L6 myotubes. In the groups of $\mathrm{H}_{2}$, Pt NPs and their combined use groups, blood sugar levels and impaired sugar tolerance of type 2 diabetes model mouse (KK- $\left.A^{y}\right)$ were significantly improved, suggesting that $\mathrm{H}_{2}$, Pt NPs and $\mathrm{H}$ are redox regulation factors in animal cells. 


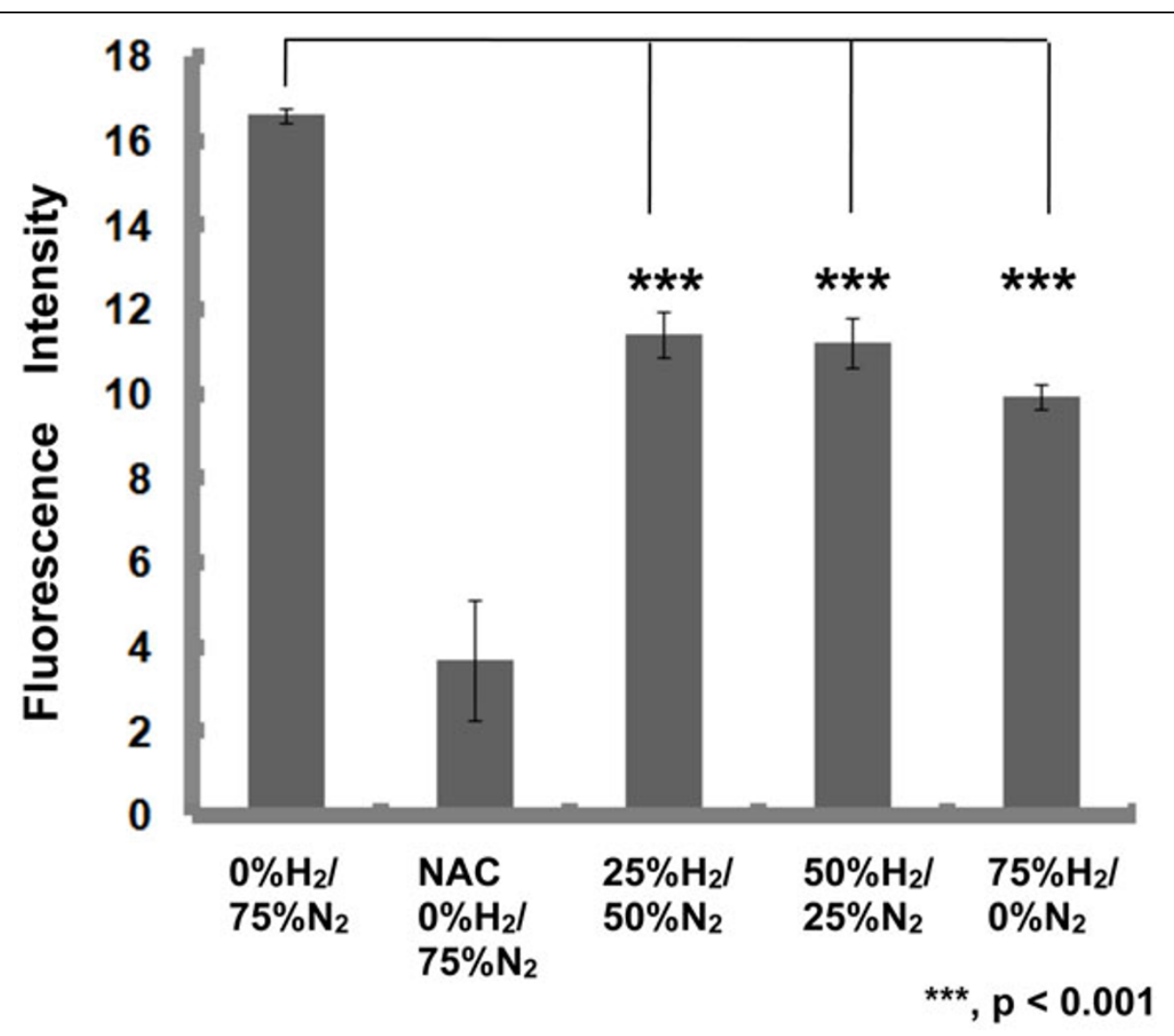

Figure 1 The scavenging effect of hydrogen molecule on intracellular hydrogen peroxide in rat myotube L6 cells. ${ }^{* * *}, p<0.001$.

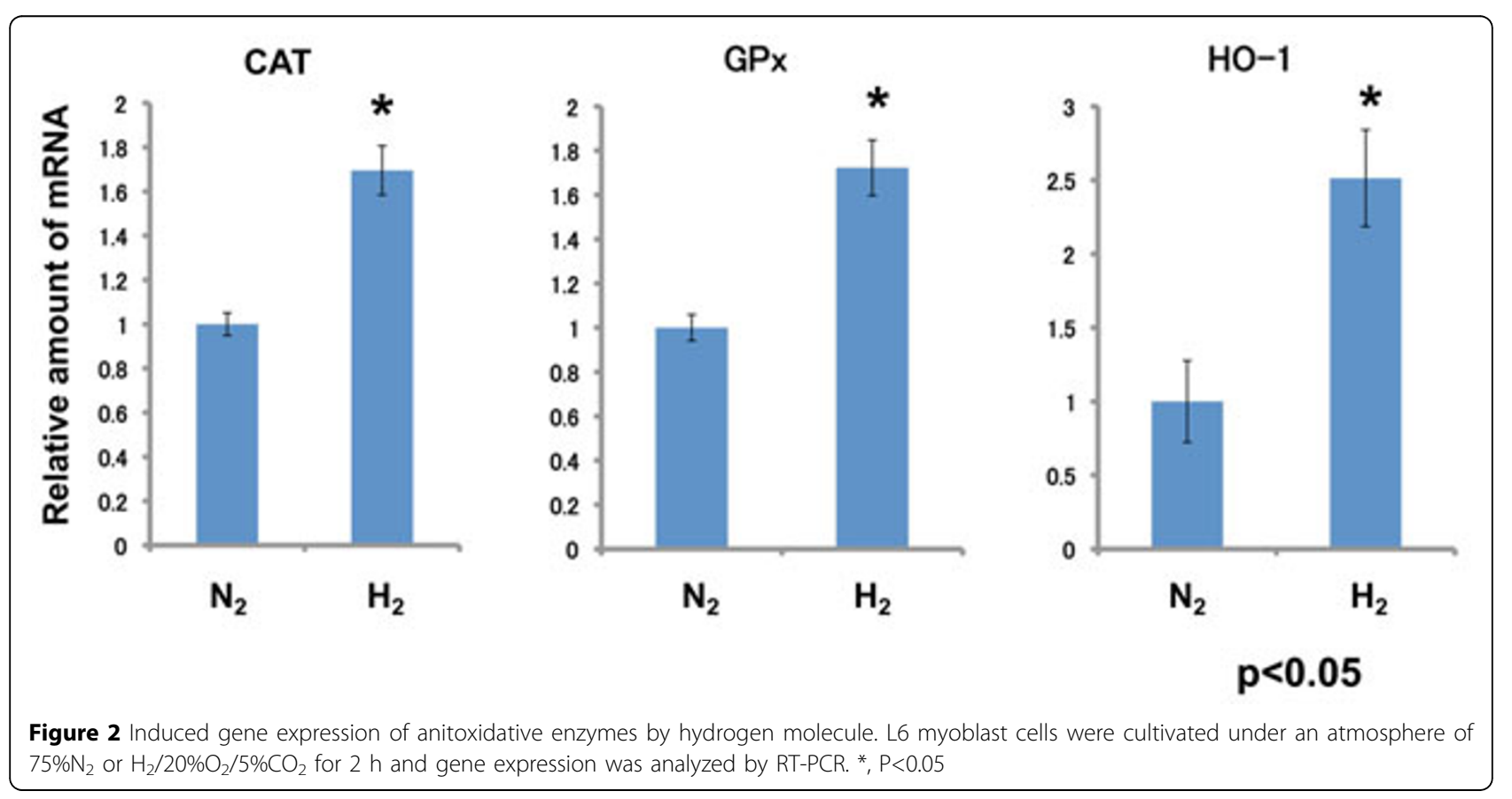




\section{Author details}

'Department of Bioscience and Biotechnology, Faculty of Agriculture, Kyushu University, 6-10-1 Hakozaki, Higashi-ku, Fukuoka 812-8581, Japan. ${ }^{2}$ Division of Life Engineering, Graduate School of Systems Life Sciences, Kyushu University, 6-10-1 Hakozaki, Higashi-ku, Fukuoka 812-8581, Japan. ${ }^{3}$ Nihon Trim Co. Ltd., 1-8-34 Oyodonaka, Kita-ku, Osaka 531-0076, Japan.

Published: 22 November 2011

\section{References}

1. Shirahata S, Kabayama S, Nakano M, Miura T, Kusumoto K, Gotoh M, Hayashi H, Otsubo K, Morisawa S, Katakura Y: Electrolyzed-reduced water scavenges active oxygen species and protects DNA from oxidative damage. Biophys Biochem Res Commun 1997, 234:269-274.

2. Yan H, Tian H, Kinjo T, Hamasaki T, Tomimatsu K, Nakamichi N, Teruya K, Kabayama S, Shirahata S: Extension of the lifespan of Caenorhabditis elegans by the use of electrolyzed reduced water. Biosci Biotech Biochem 2010, 74:2011-2015.

3. Hamasaki T, Kashiwagi T, Imada T, Nakamichi N, Aramaki S, Toh K, Morisawa S, Shimakoshi H, Hisaeda Y, Shirahata S: Kinetic analysis of superoxide anion radical-scavenging and hydroxyl radical-scavenging activities of platinum nanoparticles. Langmuir 2008, 24:7354-7364.

4. Shirahata S, Hamasaki H, Teruya K: Advanced research on the health benefit of reduced water. Trends Food Sci Tech 2011, DOI 10.1016/j. tifs.2011.10.009.

5. Li Y-P, Nishimura T, Teruya K, Maki T, Komatsu T, Hamasaki T, Kashiwagi T, Kabayama S, Shim S-Y, Katakura Y, Osada K, Kawahara T, Otsubo K, Morisawa S, Ishii Y, Gadek Z, Shirahata S: Protective mechanism of reduced water against alloxan-induced pancreatic $\beta$-cell damage: Scavenging effect against reactive oxygen species. Cytotechnology 2002, 40:139-149.

6. Li Y-P, Hamasaki T, Nakamichi N, Kashiwagi T, Komatsu T, Ye J, Teruya K, Abe M, Yan H, Kinjo T, Kabayama S, Kawamura M, Shirahata S: Suppressive effects of electrolyzed reduced water on alloxan-induced apoptosis and type 1 diabetes mellitus. Cytotechnology 2010, DOI 10.1007/s10616-0109317-6.

7. Kim M-J, Kim H-K: Anti-diabetic effects of electrolyzed reduced water in streptozotocin-induced and genetic diabetic mice. Life Sciences 2006, 79:2288-2292

8. Ohsawa I, Ishikawa M, Takahashi K, Watanabe M, Nishimaki K, Yamagata K, Katsura K, Katayama Y, Asoh S, Ohta S: Hydrogen acts as a therapeutic antioxidant by selectively reducing cytotoxic oxygen radials. Nature Med 2007, 13:688-694.

\section{doi:10.1186/1753-6561-5-S8-P18}

Cite this article as: Shirahata et al:: Anti-diabetes effect of water containing hydrogen molecule and Pt nanoparticles. BMC Proceedings 2011 5(Suppl 8):P18.

\section{Submit your next manuscript to BioMed Central and take full advantage of:}

- Convenient online submission

- Thorough peer review

- No space constraints or color figure charges

- Immediate publication on acceptance

- Inclusion in PubMed, CAS, Scopus and Google Scholar

- Research which is freely available for redistribution

Submit your manuscript at www.biomedcentral.com/submit
Biomed Central 